Renata Michalak

https://doi.org/10.26881/pwe.2020.48.03

ORCID: 0000-0002-6578-3822

Uniwersytet im. A. Mickiewicza w Poznaniu

renmi@amu.edu.pl

\title{
Doświadczanie rzeczywistości szkolnej przez uczniów edukacji początkowej
}

\section{Summary \\ The experience of school reality by primary education students}

The teacher, especially at the stage of primary education, has a significant impact on the child's development. The research intends to seek an answer to the main problem: How do early school teachers organize the education process for students due to key competences important for their functioning at subsequent stages of education? For that purpose, the experience of 387 children was examined in the following areas: possibilities of carrying out tasks in group work; the presence of outdoor education in school's everyday life; the participation of experts from outside the school in the implementation of school tasks; using students' various teaching resources, including multimedia, and undertaking research tasks. According to the following research results, teachers do not create conditions conducive to the acquisition of key competences by the students for their important function in the present and the future in school and beyond.

Keywords: organization of the education process, educational everyday life, primary education, school experiences, key competences, teacher's role

Słowa kluczowe: organizacja procesu kształcenia, codzienność edukacyjna, edukacja wczesnoszkolna, doświadczenia szkolne, kompetencje kluczowe, rola nauczyciela

\section{Wprowadzenie}

Ogromny udział w zdobywaniu doświadczeń warunkujących dobrą adaptację ucznia do zmian zachodzących w poszczególnych okresach jego życia ma środowisko szkolne. Średnie i późne dzieciństwo to czas, w którym dziecko realizuje ważną dla przebiegu jego całej kariery edukacyjnej rolę ucznia. Doświadczanie i przeżywanie codzienności edukacyjnej może temu sprzyjać, zwłaszcza gdy stają się one źródłem nabywania kompetencji kluczowych, pozwalających uczniom na podmiotowe funkcjonowanie. Z kolei mogą one także stanowić barierę dla rozwoju tych kompetencji. Jakość warunków edukacyjnych, jakie tworzy swoim uczniom szkoła, ma tu fundamentalne znaczenie. Im młodszy uczeń, tym większy jest wkład nauczyciela w kreowanie codzienności edukacyjnej. Nauczyciel, zwłaszcza na etapie edukacji początkowej, wywiera trudny do przecenienia wpływ na 
wszystkie sfery rozwoju dziecka. Niezależnie od wieku uczniów nauczyciel, jako uczestnik interakcji edukacyjnej, nigdy nie pozostaje obojętny dla procesu rozwoju dziecka. Przyjęta przez nauczyciela wizja edukacji wyznacza jego rolę i miejsce w procesie rozwoju każdego ucznia. Narzuca odpowiedni do niej sposób organizowania sytuacji edukacyjnych, które stają się źródłem i kontekstem zdobywania przez uczniów określonych doświadczeń, ważnych dla ich funkcjonowania w szkole i poza nią. Ten aspekt funkcjonowania nauczycieli stał się przedmiotem weryfikacji empirycznej podjętej przez autorkę niniejszego artykułu. W jego treści zaprezentowano i omówiono dane empiryczne dotyczące strategii organizowania procesu kształcenia przez nauczycieli edukacji początkowej reprezentowane w doświadczeniach uczniów.

\section{Strategie organizacji procesu kształcenia źródlem doświadczeń adaptacyjnych uczniów}

Odpowiednio zorganizowany proces kształcenia warunkuje autentyczny rozwój kompetencji uczniów - potwierdzają to liczne badania (por. m.in. Klus-Stańska 2000; Michalak 2004, 2011, 2013; Dąbrowski 2008; Camilli i in. 2010; Kalinowska 2010; Żytko 2010, 2011; Krauze-Sikorska 2011; Kuszak 2011; Mikołajczyk 2011; Sowińska 2011). Zależność tę podkreśla się w wielu pracach, dysputach i debatach, argumentując, że dzieci muszą być zanurzone w interaktywnym, zróżnicowanym i wyzwalającym środowisku uczenia się i to na jak najwcześniejszym etapie ich rozwoju. W związku z tym powinny często doświadczać konfliktów poznawczych, jak najczęściej pracować zespołowo, zmagać się z zadaniami problemowymi, badawczymi, wykraczającymi poza ich aktualne możliwości i mieć możliwość wykorzystywania przy tym różnych źródeł informacji. Jednocześnie ważne jest, by uczyły się w kontekście naturalnym i bliskim ich rzeczywistości, a więc jak najczęściej poza murami szkoły, włączając się w życie środowiska lokalnego. Cechy tak zarysowanego procesu kształcenia wiążą się z dobrą jego organizacją, która przekłada się na efekty w postaci nie tylko osiągnięć typowo szkolnych, ale także umiejętności kluczowych, ważnych w procesie efektywnej adaptacji do specyfiki kształcenia na kolejnych etapach edukacji (Michalak 2013).

W kontekście przytoczonych argumentów podjęto próbę weryfikacji empirycznej codzienności szkolnej kreowanej przez nauczycieli edukacji wczesnoszkolnej jako źródła doświadczeń adaptacyjnych. Przyjęto założenie, że doświadczenia uzyskiwane przez dziecko w przestrzeni edukacyjnej tworzonej przez nauczyciela edukacji wczesnoszkolnej wpływają na jakość jego funkcjonowania na kolejnym etapie edukacji szkolnej. W celu nakreślenia rzeczywistego obrazu pracy badanych nauczycieli w zakresie organizacji procesu kształcenia posłużono się techniką badania doświadczeń dzieci. Przyjęcie takiej strategii pozwoliło wyeliminować deklaratywne odpowiedzi nauczyciela i uzyskać w znacznym stopniu wiarygodne dane.

Badania zrealizowano w podejściu ilościowym, a uzyskany materiał empiryczny poddano analizie jakościowej. Głównym celem badań uczyniono rozpoznanie doświadczeń 
uczniów związanych z działaniami nauczyciela edukacji wczesnoszkolnej w zakresie organizacji procesu kształcenia. Główny problem badawczy przybrał formę: W jaki sposób nauczyciele edukacji wczesnoszkolnej organizują proces kształcenia ze względu na kluczowe kompetencje ważne dla funkcjonowania uczniów na kolejnych etapach kształcenia? Ponadto przyjęto następujące problemy szczegółowe: (1) W jaki sposób nauczyciele edukacji wczesnoszkolnej stymulują samodzielną aktywność dzieci podczas procesu kształcenia? (2) Na ile nauczyciele stosują zadania wyzwalające rzeczywistą aktywność dziecka, pozwalające na samodzielne badanie i odkrywanie rzeczywistości oraz kooperatywne działanie? (3) W jakim stopniu nauczyciele wykorzystują w codziennej pracy z uczniami metody badawcze? (4) W jakim stopniu nauczyciele wykorzystują sięgają po różnorodne środki dydaktyczne, w tym nowoczesne techniki informatyczne? (5) Na ile nauczyciele wykorzystują środowisko pozaszkolne do realizacji zadań szkolnych? (6) W jaki sposób nauczyciele włączają rodziców i ekspertów do realizacji procesu kształcenia?

Badaniami objęto 387 uczniów klasy trzeciej i prowadzono je od września do grudnia 2018 r. Próbę badawczą stanowili uczniowie klas trzecich szkół podstawowych z terenu Poznania i okolicznych gmin, którzy od pierwszej klasy byli prowadzeni przez tego samego nauczyciela. W sumie badaniami objęto 21 państwowych szkół podstawowych.

Badania miały charakter indywidualny. Osoba badająca czytała kolejno zdania charakteryzujące proces kształcenia, a dzieci oceniały, w jakim stopniu odnosiły się one do tego, co działo się w ich klasie. Do badań wykorzystano narzędzie zwane „techniką pudełkową", które zostało opracowane do badań doświadczeń szkolnych dzieci w ramach projektu badawczego nr NN 106023934 finansowanego przez Ministerstwo Nauki i Szkolnictwa Wyższego. Narzędzie to wymagało od dzieci wykonania czynności przyporządkowania kartek z opisami zdarzeń, jakie rozgrywają się w klasie, do trzech kategorii tworzących skalę częstotliwości ich występowania.

Osoba badana wprowadzała uczniów w sytuację zadaniową, korzystając z następującej instrukcji: „Przed sobą masz ustawione trzy różnokolorowe pudełka. Pudełko czerwone ma napis - prawie zawsze tak jest; pudełko niebieskie - czasami tak jest; pudełko białe - to się nie zdarza. Na karteczkach opisane są różne zdarzenia z różnych klas, jakie odwiedziłam. Przeczytaj każdą karteczkę i wrzuć ją do odpowiedniego pudełka. Jeśli zdanie na kartce mówi o czymś, co prawie zawsze ma miejsce w twojej klasie, to włóż ją do pudełka czerwonego. Jeśli w waszej klasie to się nie zdarza, włóż do pudełka białego itd. Pomogę Ci czytać karteczki (mam tu takie same), dzięki temu szybciej ukończymy zdanie, a ty czytaj razem ze mną i następnie włóż każdą przeczytaną karteczkę do odpowiedniego pudełka. Nie zastanawiaj się za długo, zrób tak, jak pomyślisz w pierwszej chwili, gdy ja będę czytała".

Przykłady zdarzeń zapisanych na kartkach: 1) Na zajęciach pracujemy w grupach i wspólnie wykonujemy różne projekty, plakaty, piszemy opowiadania itp. 2) Nasza pani zaprasza na nasze lekcje różnych gości, którzy razem z panią prowadzą ciekawe zajęcia i opowiadają o swojej pracy. 3) W czasie pracy na lekcji trzeba grzecznie siedzieć w ławce. 4) Dzieci przynoszą z domu różne ciekawe przedmioty, gry, książki. 
Uzyskane dane ujęto w kategorie ze względu na charakter zdarzenia opisanego na kartkach i przydzielono im określoną liczbę punktów z uwagi na częstotliwość występowania. Jeśli dziecko uznało, że dane zdarzenie, które miało pozytywny charakter, występuje „prawie zawsze”, wówczas przydzielano 2 punkty; jeśli „czasami”, to przydzielano 1 punkt; natomiast na 0 punktów oceniono odpowiedź „to się nie zdarza”. Odwrotną punktację zastosowano w wypadku oceny częstotliwości występowania zdarzeń o charakterze negatywnym. Wzięto pod uwagę pięć kategorii doświadczeń trzecioklasistów:

1. Możliwość realizacji zadań w pracy grupowej;

2. Obecność outdoor education w codzienności szkolnej;

3. Udział ekspertów spoza szkoły w realizacji zadań szkolnych;

4. Korzystanie z różnorodnych środków dydaktycznych, w tym multimediów;

5. Podejmowanie zadań badawczych.

W związku z tym odpowiedzi każdego dziecka można było maksymalnie wycenić na 10 punktów (każda kategoria była reprezentowana przez dwa zdarzenia, jedno o charakterze pozytywnym i jedno - negatywnym). Liczba punków uporządkowana na skali określiła zakres pozytywnych doświadczeń dziecka związanych z organizacją procesu kształcenia:

- 0-3 punktów: niski zakres pozytywnych doświadczeń;

- 4-7 punktów: przeciętny zakres pozytywnych doświadczeń;

- 8-10 punktów: duży zakres pozytywnych doświadczeń.

Szczegółowe wyniki dotyczące całej populacji badanych uczniów zilustrowano w tabeli 1.

Tabela 1. Doświadczenia dzieci związane z organizacją procesu kształcenia. Rozkład dla wszystkich 5 kategorii doświadczeń $(\mathrm{N}=387)$

\begin{tabular}{|l|c|c|}
\hline \multicolumn{1}{|c|}{ Zakres pozytywnych doświadczeń } & Liczba uczniów & Odsetek uczniów (\%) \\
\hline niski & 175 & 45,22 \\
\hline przeciętny & 144 & 37,21 \\
\hline duży & 68 & 17,57 \\
\hline
\end{tabular}

Źródło: badania własne.

Rozkład danych empirycznych pokazuje, że jedynie $17,57 \%$ badanych dzieci posiada duży zakres pozytywnych doświadczeń związanych z możliwością działania w bogatym środowisku aktywnego uczenia się. Niski zakres pozytywnych doświadczeń pod względem organizacji procesu kształcenia deklaruje blisko połowa dzieci. W kontekście zgromadzonych danych empirycznych można stwierdzić, że sposób organizowania warunków edukacyjnego rozwoju dzieci w rzeczywistości szkolnej nadal ma charakter transmisyjny, charakteryzujący się niską atrakcyjnością w zakresie form i metod pracy, zamknięty na osobiste doświadczenia dziecka, odizolowany od realnego życia, oparty na dominacji nauczyciela i bierności poznawczej ucznia. 
W celu ukazania głównych cech modelu organizacji procesu kształcenia preferowanego przez badanych nauczycieli podjęto próbę zaprezentowania szczegółowych danych ilustrujących doświadczenia dzieci w zakresie: możliwości realizacji zadań w pracy grupowej; obecności outdoor education w codzienności szkolnej; udziału ekspertów spoza szkoły w realizacji zadań szkolnych; korzystania uczniów z różnorodnych środków dydaktycznych, w tym multimediów, oraz podejmowania zadań badawczych. W tabeli 2 zaprezentowano wyniki dla poszczególnych kategorii doświadczeń uczniów klas trzecich. Podstawą kwalifikacji doświadczeń do poszczególnych kategorii była liczba przypisanych punktów do odpowiedzi uczniów (0-2).

Tabela 2. Doświadczenia dzieci związane z poszczególnymi aspektami organizacji procesu kształcenia $(\mathrm{N}=387)$

\begin{tabular}{|c|c|c|}
\hline $\begin{array}{l}\text { Zakres pozytywnych } \\
\text { doświadczeń }\end{array}$ & Liczba uczniów & Odsetek uczniów (\%) \\
\hline \multicolumn{3}{|c|}{ Realizacja zadań w pracy grupowej } \\
\hline niski & 119 & 30,75 \\
\hline przeciętny & 188 & 48,58 \\
\hline duży & 80 & 20,67 \\
\hline \multicolumn{3}{|c|}{ Obecność outdoor education } \\
\hline niski & 239 & 61,76 \\
\hline przeciętny & 117 & 30,23 \\
\hline duży & 31 & 8,01 \\
\hline \multicolumn{3}{|c|}{ Udzial ekspertów spoza szkoły w realizacji zadań szkolnych } \\
\hline niski & 285 & 73,64 \\
\hline przeciętny & 85 & 21,97 \\
\hline duży & 17 & 4,39 \\
\hline \multicolumn{3}{|c|}{$\begin{array}{l}\text { Korzystanie z różnorodnych środków dydaktycznych } \\
\text { (multimedia oraz narzędzia badawcze) }\end{array}$} \\
\hline niski & 118 & 30,49 \\
\hline przeciętny & 153 & 39,54 \\
\hline duży & 116 & 29,97 \\
\hline \multicolumn{3}{|c|}{ Obecność zadań badawczych } \\
\hline niski & 114 & 29,46 \\
\hline przeciętny & 177 & 45,74 \\
\hline duży & 96 & 24,80 \\
\hline
\end{tabular}

Źródło: badania własne. 
Przygotowanie uczniów do życia we współczesnym świecie, w którym najważniejszym kapitałem staje się wiedza, wymaga zbudowania lub co najmniej modyfikacji koncepcji realizowania przez szkołę jej podstawowych funkcji. Najogólniej można powiedzieć, że zmiany te mają przede wszystkim dotyczyć sposobów kształcenia, a mówiąc literalnie - rezygnacji z transmisji gotowych znaczeń na rzecz przygotowania ucznia do ich tworzenia. Chodzi więc o wyposażenie ucznia w narzędzia uczenia się niezbędne do poznawania rzeczywistości, porządkowania wiedzy o niej i wykorzystywania tej wiedzy. Ponadto chodzi o daleko idącą indywidualizację procesów dydaktycznych, które mają sprzyjać maksymalizacji potencjału rozwojowego każdego ucznia. Zatem optymalizacja szans edukacyjnych każdego uczącego się jest ciągle priorytetowym zadaniem szkoły.

Współczesny świat oczekuje od ludzi: umiejętności współpracy, zdolności do negocjacji, pokojowego współistnienia i demokratycznego uczestnictwa w procesach warunkujących jego pomyślny rozwój. Możliwość ich rozwinięcia tkwi w sytuacjach, w których następuje konieczność konfrontacji ze sobą wielu stanowisk, zdań, opinii i przekonań. $\mathrm{W}$ edukacji szkolnej takie sytuacje pojawiają się podczas pracy zespołowej i w grupowym podejściu do zadań. Tymczasem - jak wykazano w badaniach - możliwość realizacji zadań w pracy grupowej nadal zbyt rzadko jest wpisana w codzienność szkolną dzieci w edukacji wczesnoszkolnej. Jedynie niespełna co drugi badany uczeń w przeciętnym stopniu doznaje pozytywnych doświadczeń w tym zakresie, prawie $31 \%$ badanych uczniów zaś wskazuje na niski ich zakres. Praca w małych grupach rówieśniczych ułatwia uczniom precyzowanie wiedzy przez argumentację, wymianę osobistych doświadczeń, dzielenie się osobistym rozumieniem, negocjowanie i rozstrzyganie sprzeczności. Powoduje, że uczniowie dużo chętniej podejmują się rozwiązania problemów trudnych, skomplikowanych i ryzykownych, gdyż czują wsparcie pozostałych członków. Różnica perspektyw ujmowania świata (dzieci pochodzą z różnych rodzin, mają różne osobiste doświadczenia) jest bardzo ważnym źródłem konfliktów poznawczych stymulujących rozwój. Praca w małych grupach stanowi także: źródło pomysłów i wyzwań; układ odniesienia dla porównań społecznych; źródło pomocy i wsparcia w trudnych sytuacjach ze względu na bliskość psychiczną i podobne rozumienie świata (Michalak 2013).

Efektywna i atrakcyjna dla uczniów organizacja procesu kształcenia prowadząca do rozwoju kompetencji kluczowych dla ich funkcjonowania zarówno w przestrzeni szkolnej, jak i pozaszkolnej, polega na tworzeniu sytuacji, w których uczeń zdobywa wiedzę i umiejętności w bliskim i naturalnym dla siebie kontekście. Uczenie się w takim kontekście prowadzi do rozwoju bogatych i głębokich struktur wiedzy, co z kolei przyczynia się do lepszego transferowania wiedzy w nowych, nietypowych sytuacjach nacechowanych zmianą. Zatem propagowanie outdoor education ma sens ze względu na sam proces kształcenia, który jest efektywny i atrakcyjny dla uczniów. Zajęcia w terenie pozwalają dzieciom na dużą swobodę poruszania się i komunikowania. Swoboda i radość eliminują stres, który tak często pojawia się podczas typowych zajęć szkolnych. Środowisko poza murami szkoły stanowi także źródło naturalnych środków dydaktycznych istotnych w procesie kształcenia. Niestety, taki typ edukacji niezmiernie rzadko jest realizowany 
w pracy z najmłodszymi uczniami. Do podobnych wniosków skłaniają także wyniki badań przeprowadzonych przez Renatę Michalak i Teresę Parczewską (2019).

Dane empiryczne zaprezentowane $\mathrm{w}$ tabeli 2 pokazują, że znaczny procent uczniów $(61,76 \%)$ ma niski zakres pozytywnych doświadczeń w zakresie outdoor education. Nauczyciele nie wychodzą z dziećmi poza mury szkolne lub czynią to niezmiernie rzadko, nie organizują procesu kształcenia w naturalnym i bliskim dziecku środowisku, nie zapraszają też osób ze środowiska do wspólnej realizacji tego procesu. Prawie $74 \%$ badanych dzieci posiada jedynie niski zakres pozytywnych doświadczeń w zakresie udziału ekspertów spoza szkoły w realizacji procesu kształcenia. Uczniowie uczą się w sztucznym środowisku, oderwanym od ich rzeczywistych doświadczeń.

Przygotowanie ucznia do krytycznego korzystania z różnych źródeł wiedzy wymaga stosowania zróżnicowanych środków dydaktycznych zarówno co do treści, funkcji, jak i formy. Proces kształcenia oparty na bogactwie środków jest szczególnie istotny ze względu na potrzeby rozwojowe dzieci i ich zasoby. Sposób poznawania przez uczniów na poziomie wczesnoszkolnym jest ograniczony do percepcji konkretnego materiału. Dziecko na tym etapie kształcenia potrzebuje jeszcze wielu konkretnych wrażeń zmysłowych, by mogło efektywnie konstruować odpowiednie struktury poznawcze. Dla procesu kształtowania kompetencji kognitywnych udział materiału dydaktycznego w formie bezpośrednich doświadczeń ma kluczowe znaczenie. Materiał w postaci środków dydaktycznych stanowi pomost od wyobrażeń konkretnych do symbolicznych, od myślenia konkretno-wyobrażeniowego do myślenia abstrakcyjnego (Wadsworth 1998; Matczak 2003; Bee 2004). Pomoce dydaktyczne, zwłaszcza w formie mediów elektronicznych, stanowią cenne źródło aktualnych informacji, jak również środek ich przetwarzania oraz narzędzie uczenia się. Umiejętność korzystania z Internetu staje się koniecznością i zarazem kluczową kompetencją współczesnego człowieka, na co zwracają uwagę m.in. zwolennicy najnowszej teorii uczenia się - konektywizmu. Komputer, iPad, smartfon stanowią zewnętrzny nośnik pamięci - z zakodowanych w niej różnych treści czerpie uczeń, wzbogacając własną wiedzę poprzez rozwiązywanie problemów zarówno indywidualnych, jak i społecznych. Uczenie się zgodne z założeniami konektywizmu powinno się koncentrować na znajdowaniu wiedzy. Know-where jest tu ważniejsze niż know-what i know-how, zwłaszcza w świecie, w którym zachodzą tak dynamiczne i nieprzewidywalne zmiany. Uczenie się jest zatem konstruowaniem sieci powiązanych ze sobą obiektów i zdarzeń, ,jest procesem włączenia się w nowe źródła wiedzy” (Gawrysiak 2010: 351). Tak ujęty proces uczenia się wymaga opanowania kluczowych umiejętności zarządzania informacją, takich jak poszukiwanie i selekcja informacji, ocena jej użyteczności oraz tworzenie sieci powiązań między informacjami. Technika zatem staje się nieodłącznym środkiem i kontekstem uczenia się. Do synergii edukacji i techniki potrzebne są podstawowe umiejętności korzystania z mediów, które należy kształtować już od jak najwcześniejszych lat. Tymczasem - jak pokazano w badaniach - szkoła jest zamknięta na ten proces. Najmłodsi uczniowie nie mają w zasadzie szans na korzystanie $\mathrm{z}$ komputera, telefonu komórkowego i innych nośników informacji w trakcie zajęć szkolnych. Środki te nie tylko nie 
stanowią wsparcia dla nauczycieli w procesie organizowania sytuacji edukacyjnych, ale bywają oceniane jako szkodliwe, a korzystanie z nich przez uczniów na terenie szkoły bywa wręcz karane. Urządzenia mobilne posiadają ogromny potencjał edukacyjny, ponieważ pozwalają w rzeczywistym czasie nałożyć informacje generowane cyfrowo i interaktywnie na obraz świata rzeczywistego. Doskonale odwzorowują rzeczywistość, co pozwala przećwiczyć zachowania i sprawdzić umiejętności. Można je odpowiednio wpasować w program nauczania. Ich wielki potencjał leży we ,wspieraniu rozwoju współpracy, rozwiązywania rzeczywistych problemów i myślenia proceduralnego" (Johnson i in. 2011: 5). Codzienność szkolna dziecka jest uboga pod względem środków dydaktycznych sprzyjających podejmowaniu działań twórczych, badawczych i eksploracyjnych. Dzieci niezmiernie rzadko korzystają w toku codziennej pracy z narzędzi laboratoryjnych i poglądowego materiału badawczego, gdyż nie prowadzą działalności o charakterze badawczym, co pokazują wyniki badań. Prawie 30\% badanych trzecioklasistów dysponuje niskim zakresem pozytywnych doświadczeń w tym obszarze działalności edukacyjnej. Aktywność badawcza ma natomiast duże walory w zakresie stymulowania rozwoju dziecka. Stwarza ona szczególnie dogodne warunki do samodzielnego nabywania i rozwijania przez uczniów zarówno wiedzy i umiejętności poznawczych, jak i technik adaptacyjnych. Aktywność badawcza dostarcza dzieciom doświadczeń istotnych dla kształtowania pojęć naukowych, rozumienia zjawisk i powiązań między nimi oraz rozwijania podstawowych operacji umysłowych, takich jak: synteza, analiza, klasyfikacja, porównywanie, abstrahowanie i wnioskowanie. Jednocześnie przyczynia się ona do rozwijania samodzielności w myśleniu i rozumowaniu dziecka w wyniku stopniowego weryfikowania w trakcie samodzielnego gromadzenia materiału badawczego pierwotnych pomysłów i przypuszczeń. Dziecko, zmagając się z zadaniami o charakterze badawczym, wchodzi w rolę poszukiwacza i odkrywcy wiedzy, samodzielnie dostrzega problemy, braki w danych, tworzy hipotezy i wypracowuje strategie ich weryfikacji. W naturalny sposób dostrzega wówczas zależności, odkrywa związki, selekcjonuje i kategoryzuje dane, zaczyna rozumieć z pozoru bardzo trudne zjawiska i procesy. Zadania badawcze poza niewątpliwymi walorami poznawczymi tworzą także bardzo atrakcyjny kontekst edukacyjny, który pochłania dziecko, przeżycia związane z tym kontekstem wyzwalają w nim emocje i skłaniają do nawiązywania relacji społecznych. Zadania te dają też dziecku okazję do kształtowania poczucia własnej wartości. Mimo tak licznych zalet działalność badawcza niezmiernie rzadko jest obecna w kształceniu najmłodszych uczniów, co może budzić uzasadniony niepokój.

\section{Zakończenie}

W kontekście omówionych wyników badań obraz środowiska edukacyjnego jako źródła doświadczeń istotnych dla kształtowania kompetencji kluczowych dzieci, w tym warunkujących ich konstruktywną i podmiotową adaptację do zmieniających się warunków edukacyjnych, jawi się w mało korzystnym świetle. Badani nauczyciele kreują rzeczywistość szkolną daleką nie tylko od zmian zachodzących w realnym świecie, w którym uczniowie 
funkcjonują, od aktualnych założeń teorii rozwoju i uczenia się oraz od dziecięcych zainteresowań, ale też przede wszystkim od potrzeb rozwojowych uczniów. Treść szkolnych doświadczeń dziecka nie pomaga mu w budowaniu trwałych i zróżnicowanych struktur psychicznych warunkujących jego aktywne funkcjonowanie w szkolnej i pozaszkolnej teraźniejszości, a tym bardziej w przyszłości. Doświadczenia szkolne często wręcz redukują struktury najbardziej istotne dla wzrastania dziecka i efektywnego pokonywania progów edukacyjnych. Tym samym nie sprzyjają one adaptacji szkolnej uczniów o charakterze prorozwojowym. Doświadczenia adaptacyjne stanowią bowiem ważny element doświadczeń gromadzonych przez dzieci w codziennych sytuacjach życia szkolnego. Edukacja, która dostarcza cennych rozwojowo doświadczeń, jest jednocześnie edukacją sprzyjającą aktywnej, konstruktywnej i podmiotowej adaptacji, co pokazują wyniki badań zaprezentowane przez autorkę artykułu we wcześniejszej publikacji (Michalak 2013). Jakość edukacji warunkuje przebieg procesu adaptacji i szanse ucznia na efektywne pokonanie wszystkich trudności, które pojawiają się wraz ze zmieniającą się szkolną codziennością.

\section{Literatura}

Bee H. (2004), Psychologia rozwoju człowieka. Poznań, Wydawnictwo Zysk i S-ka.

Camilli G., Vargas S., Ryan S., Barnett W.S. (2010), A meta-analysis of the effects of early education interventions on cognitive development. „Teachers College Record”, 112(3).

Dąbrowski M. (2008), Pozwólmy dzieciom myśleć. O umiejętnościach matematycznych polskich trzecioklasistów. Warszawa, CKE.

Gawrysiak M. (2010), Wytresowany pies czy autonomiczny kot? O edukacji komputacjonistycznej, konstruktywistycznej i konektywistycznej. W: Z. Melosik, B. Śliwerski (red.), Edukacja alternatywna XXI wieku. Kraków, Oficyna Wydawnicza „Impuls”.

Johnson L., Smith R., Willis H., Levine A., Haywood K. (2011), The 2011 Horizon Report. Austin, Texas, The New Media Consortium.

Kalinowska A. (2010), Pozwólmy dzieciom działać. Mity i fakty o rozwijaniu myślenia matematycznego. Warszawa, CKE.

Klus-Stańska D. (2000), Konstruowanie wiedzy w szkole. Olsztyn, Wydawnictwo Uniwersytetu Warmińsko-Mazurskiego w Olsztynie.

Krauze-Sikorska H. (2011), Praca z dziećmi o specjalnych potrzebach edukacyjnych i jej implikacje dla ich rozwoju. W: H. Sowińska (red.), Dziecko w szkolnej rzeczywistości. Założony a rzeczywisty obraz edukacji elementarnej. Poznań, Wydawnictwo Naukowe Uniwersytetu im. Adama Mickiewicza.

Kuszak K. (2011), Kompetencje komunikacyjne dzieci w okresie późnego dzieciństwa w aspekcie rozwojowym. Poznań, Wydawnictwo Naukowe Uniwersytetu im. Adama Mickiewicza.

Matczak A. (2003), Zarys psychologii rozwoju. Warszawa, Wydawnictwo Akademickie Żak.

Michalak R. (2004), Aktywizowanie ucznia w edukacji wczesnoszkolnej. Poznań, Wydawnictwo Naukowe UAM.

Michalak R. (2011), Poznawanie świata przyrody jako kontekst ksztattowania kompetencji poznawczych trzecioklasistów. W: H. Sowińska (red.), Dziecko w szkolnej rzeczywistości. Założony a rzeczywisty obraz edukacji elementarnej. Poznań, Wydawnictwo Naukowe UAM. 
Michalak R. (2013), Dziecko u progu edukacji przedmiotowej. Studium teoretyczno-empiryczne. Poznań, Wydawnictwo Naukowe UAM.

Michalak R., Parczewska T. (2019), (Nie)obecność outdoor education w ksztatceniu szkolnym. Lublin, Wydawnictwo Naukowe UMCS.

Mikołajczyk K. (2011), Kompetencje emocjonalne dziecka w późnej fazie dzieciństwa. W: H. Sowińska (red.), Dziecko w szkolnej rzeczywistości. Założony a rzeczywisty obraz edukacji elementarnej. Poznań, Wydawnictwo Naukowe Uniwersytetu im. Adama Mickiewicza.

Sowińska H. (2011), Rozwój kompetencji społecznych dziecka na etapie edukacji wczesnoszkolnej. W: H. Sowińska (red.), Dziecko w szkolnej rzeczywistości. Założony a rzeczywisty obraz edukacji elementarnej. Poznań, Wydawnictwo Naukowe Uniwersytetu im. Adama Mickiewicza.

Wadsworth B.J. (1998), Teoria Piageta. Poznawczy i emocjonalny rozwój dziecka. Warszawa, WSiP. Żytko M. (2010), Pozwólmy dzieciom mówić i pisać. W kontekście badań umiejętności trzecioklasistów. Warszawa, CKE.

Żytko M. (2011), Pozwólmy dzieciom bawić się słowami. O doświadczeniach językowych trzecioklasistów. Warszawa, CKE. 